\title{
Front Matter: Volume 11630
}

, "Front Matter: Volume 11630," Proc. SPIE 11630, Optical Coherence Tomography and Coherence Domain Optical Methods in Biomedicine XXV, 1163001 (27 April 2021); doi: 10.1117/12.2596814

SPIE. Event: SPIE BiOS, 2021, Online Only 


\section{PROGRESS IN BIOMEDICAL OPTICS AND IMAGING}

\section{Optical Coherence Tomography and Coherence Domain Optical Methods in Biomedicine XXV}

Joseph A. Izatt

James G. Fujimoto

Editors

6-11 March 2021

Online Only, United States

Sponsored and Published by

SPIE 
The papers in this volume were part of the technical conference cited on the cover and title page. Papers were selected and subject to review by the editors and conference program committee. Some conference presentations may not be available for publication. Additional papers and presentation recordings may be available online in the SPIE Digital Library at SPIEDigitalLibrary.org.

The papers reflect the work and thoughts of the authors and are published herein as submitted. The publisher is not responsible for the validity of the information or for any outcomes resulting from reliance thereon.

Please use the following format to cite material from these proceedings:

Author(s), "Title of Paper," in Optical Coherence Tomography and Coherence Domain Optical Methods in Biomedicine XXV, edited by Joseph A. Izatt, James G. Fujimoto, Proc. of SPIE 11630 , Seven-digit Article CID Number (DD/MM/YYYY); (DOI URL).

ISSN: 1605-7422

ISSN: 2410-9045 (electronic)

ISBN: 9781510640955

ISBN: 9781510640962 (electronic)

Published by

SPIE

P.O. Box 10, Bellingham, Washington 98227-0010 USA

Telephone +13606763290 (Pacific Time)

SPIE.org

Copyright @ 2021 Society of Photo-Optical Instrumentation Engineers (SPIE).

Copying of material in this book for internal or personal use, or for the internal or personal use of specific clients, beyond the fair use provisions granted by the U.S. Copyright Law is authorized by SPIE subject to payment of fees. To obtain permission to use and share articles in this volume, visit Copyright Clearance Center at copyright.com. Other copying for republication, resale, advertising or promotion, or any form of systematic or multiple reproduction of any material in this book is prohibited except with permission in writing from the publisher.

Printed in the United States of America by Curran Associates, Inc., under license from SPIE.

Publication of record for individual papers is online in the SPIE Digital Library.

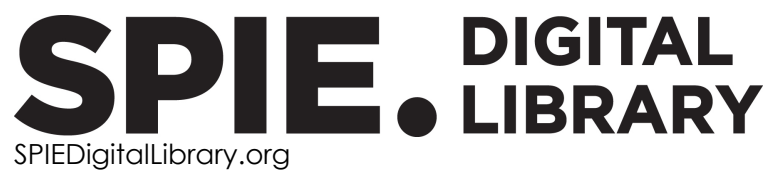

Paper Numbering: A unique citation identifier (CID) number is assigned to each article in the Proceedings of SPIE at the time of publication. Utilization of CIDs allows articles to be fully citable as soon as they are published online, and connects the same identifier to all online and print versions of the publication. SPIE uses a seven-digit CID article numbering system structured as follows:

- The first five digits correspond to the SPIE volume number.

- The last two digits indicate publication order within the volume using a Base 36 numbering system employing both numerals and letters. These two-number sets start with 00, 01, 02, 03, 04, 05, 06, 07, 08, 09, 0A, OB ... 0Z, followed by 10-1Z, 20-2Z, etc. The CID Number appears on each page of the manuscript. 


\section{Contents}

NEURAL/BRAIN

$116300 \mathrm{~A}$ Optical coherence angiography to assess the combined effects of alcohol and nicotine on fetal brain vasculature [11630-6]

OPHTHALMIC NEW TECHNOLOGY

$11630 \mathrm{ON}$ Retinal phantom mimicking superficial vascular networks and full retinal layers for OCT and OCT-angiography [11630-19]

\section{GI/PULMONARY NEW TECHNOLOGY}

11630 OT Evaluation of machine learning techniques for Barret's and dysplasia discrimination of the esophagus from in vivo optical coherence tomography images [11630-25]

MACHINE LEARNING/IMAGE PROCESSING

1163010 A GCN-assisted deep learning method for peripapillary retinal layer segmentation in OCT images [11630-32]

1163012 Artefact removal for quantum optical coherence tomography using machine learning [11630-34]

NOVEL CONTRAST

1163017 Characterization of RBC flux and velocity measurements in OCT with concurrent two-photon microscopy [11630-39]

MICROSTRUCTURE IMAGING

1163019 Single-shot 4-phase shifting optical coherence microscopy [11630-41]

$116301 \mathrm{E} \quad \mathrm{OCT}$ based cross-sectional and three-dimensional dynamics imaging for visualization and quantification of tumor spheroid activity [11630-46] 
$11630 \mathrm{lF} \quad$ Mirau-type full-field optical coherence tomography [1 1630-47]

$1163016 \quad$ Dynamic optical coherence microscopy with model-based motion reduction [1 1630-48]

\section{OCT NEW TECHNOLOGY}

$116301 \mathrm{M} \quad$ Advantage of low NEP balanced receivers in swept source OCT [1 1630-54]

$116301 \mathrm{~N} \quad$ Motion-compensated optical coherence tomography based on higher-order regression for real-time volumetric imaging [1 1630-55]

\section{POSTER SESSION}

$116301 Q \quad$ Volumetric multi-contrast dynamics imaging for ex vivo liver microvasculature activity visualization using Jones matrix optical coherence tomography [1 1630-58]

$116301 \mathrm{R} \quad$ Optical coefficients as tools for increasing the optical coherence tomography contrast for breast cancer margin detection [11630-59]

11630 is Creating a depth-resolved OCT-dataset for supervised classification based on ex vivo human brain samples [11630-60]

$116301 \mathrm{~T} \quad$ Characterization of brain tumor tissue with $1310 \mathrm{~nm}$ optical coherence tomography [11630-61]

$116301 \mathrm{U} \quad$ Heartbeat optical coherence elastography: using heartbeat to measure corneal biomechanical properties [1 1630-62]

1163012 Deep-learning for thyroid microstructure segmentation in 2D OCT images [11630-67]

$1163020 \quad$ Multi-contrast imaging with computational refocusing in polarization-sensitive optical coherence tomography [1 1630-68]

$1163021 \quad$ Sample and system parameter estimation from local speckle pattern by fully numerically trained deep convolution neural network [1 1630-69]

$1163023 \quad$ OCT applications in optics R\&D and manufacturing [11630-71]

1163024 Development of dual-side view swept source optical coherence tomography for opaque materials thickness measurement [11630-72]

1163026 An iterative algorithm for artifacts removal in Fourier-domain optical coherence tomography [1 1630-74] 